*Forthcoming (2017) in the Journal of International Relations and Development as part of a special issue on 'Political Theologies of the International: The Continued Relevance of Theology in International Relations'

(Accepted for publication $26^{\text {th }}$ February 2016)

\title{
First Image Revisited: Human Nature, Original Sin and International Relations
}

It is not because it is too profound, but rather because it is too uncomfortable, that you shy away from the truth

-Paul Tillich

\section{Vassilios Paipais}

University of St Andrews

\section{Introduction}

In realist theories of international relations, human nature is standardly classified as one of the three causes of war. In Kenneth Waltz's famous tripartite distinction, human nature's propensity to evil is catalogued as a first-image cause of war. However, Waltz himself seems to quickly dismiss first-image explanations of war as scientifically unreliable due to human nature's complexity and inscrutability. Customarily, human nature explanations of conflict are criticised for resting on metaphysical assumptions and apriori pessimism. This paper argues that standard realist conceptions about the inherent evilness of human nature or, equally, reductionist sociobiological accounts of its hard-wired conflict-proneness are impoverished secularised versions of Christian anthropological assumptions grounded on the doctrine of original sin. Itself a widely contested dogma, in its Augustinian formulation original sin was linked to a soteriological perspective, that is, a defence of its status as a corollary to the doctrine that all human beings are equally in need of salvation in Christ. However, its use was never entirely disconnected from purposes of theodicy and Christian apologetics striving to 
reconcile the co-existence of a benevolent and omnipotent God with the reality of evil and suffering in the world.

It is this latter legacy -associated with the explanation of suffering and evil in the world but stripped of its eschatological content- that pervades secularist theorisations of human nature. Prominent part in this semantic transfiguration is played by a post-Augustinian understanding of human nature as the repository of passions, drives and vices that need to be tamed by an imposing human will representing the source of human personhood. As a result, natural human passions such as pain and suffering or the human condition itself, i.e. finitude and mortality, were seen as evil or punishment resulting from sin. With the eclipse of the eschatological dimension, human nature was gradually reduced to its physical, naturalistic aspects, equated with aggressive drives, and eventually autonomised as a causal explanation of conflict and human suffering. Initially conceived as a meditation on the paradox of evil and human responsibility, original sin ended up signifying man's inherent wickedness. This paper will argue that even though the doctrine's ambiguity permitted its naturalisation, the paradox at its heart rests on a fragmented theological anthropology inseparable from a redemptive dimension. International Relations will only hold impoverished notions of the role of human nature in international politics should it go on neglecting the complexity of a doctrine that was far from offering a reductionist vision of the human condition.

\section{Naturalising original sin}

In standard IR textbooks, 'human nature' is traditionally associated with realist explanations of war located at the level of the individual -the other two causes of war being regime type operating at the level of the state and anarchy characterising the structure of the international system (Donnelly 2000; Brown 2005; Burchill et al 2009; Nicholson 2002). Kenneth Waltz's (1959) Man, State and War is generally recognised as the inaugural statement of this classification. Through a sweeping perusal of the individual motivations that lead men to war in the history of political thought, human nature in Waltz's text is typified as part of a tradition that attributes war to man's evil inclinations. The idea here is not only that human nature is inherently wicked and bellicose but also that it is fixedly so, i.e. permanently and 
unredeemably defective and unamenable to transformation, amelioration or salvation.

In the course of his argument, Waltz (1959: 23) unquestionably assumes that the roots of this pessimist view on human nature can be found in the Christian tradition harking back to Augustine and his emphasis on original sin: 'the act that accounts for the fact that human reason and will are both defective'. Here, Waltz rather clumsily lumps together a series of thinkers in that contrived tradition -from Luther, Hobbes and Spinoza in early modern times to Morgenthau and Niebuhr in the twentieth century. To say the least, these thinkers shared a rather disparate understanding of pessimism and the reasons behind human nature's proclivity to evil. Waltz seems to suggest that Augustine inaugurates the tradition that leads to the identification of original sin with man's primordial and inescapable wickedness. Yet, he doesn't seem interested in making subtle distinctions as to what this statement implies in terms of the relationship between man's moral agency, his biological nature and his worldly existence. For, it is one thing to foreground a tradition that is pessimistic about man's ability to permanently secure peace and progress on earth, and quite another to attribute such an inability to metaphysical, transhistorical assumptions about human nature (Dienstag 2009a).

Waltz's treatment may, then, be seen as at the roots of caricature textbook readings of realist thought that abound in the discipline and tend to rely on this rather reified view of 'what moves man' (Freyberg-Inan 2004). The problem, however, runs deeper than a simple misinterpretation, misrepresentation or even misclassification for the purposes of advancing a scholarly agenda. It reflects the implications of the severance of the social sciences from its moorings in the history of political thought. ${ }^{1}$ It also reflects the effects of what Mark Lilla (2007) describes as the 'Great Separation', the gradual secularisation of the study of social phenomena and the insulation of the study of political concepts from their provenance in non-secular discourses. Alastair McIntyre's (1990) argument that we are condemned to live with

\footnotetext{
${ }^{1}$ There are signs that the tides are changing on that front and that political and social theorists are beginning to grapple with the real complexity of modernity's relationship to religion. To note just a few examples, see Charles Taylor (2007), Michael Gillespie (2008), Mark Lilla (2007), and Jean Bethke Elshtain (2008). For a good overview, see Rengger (2013). Of course, the greatest indicator of these trends is that even certain Rawlsians are trying to engage this conversation in new ways, most notably through the publication of Rawls' (2009) own undergraduate thesis, A Brief Inquiry into the Meaning of Sin and Faith, a work of Protestant theology.
} 
fragments of traditions that are only minimally intelligible to us due to modernity's radical change of paradigm is more than relevant here. ${ }^{2}$

Unsurprisingly, then, Waltz is not alone in the history of international political thought in sanctioning such an illegitimate confluence. Carl Schmitt's concept of the political can also be seen as resting on an interpretation of the original sin as fixed conflict-proneness. Schmitt (2008: 58) believes that there are two kinds of political theories: those ones that presuppose a conception of human nature as evil and take original sin seriously; and those ones that either gloss over this fact or deny it altogether imagining human nature as inherently good or positively malleable. Heinrich Meier (1995: 57) goes as far as to claim that '[o]riginal sin is the central point around which everything turns in [Schmitt's] anthropological confession of faith.' In this aspect, Schmitt is closely aligned with those Catholic authoritarians he so strongly admired, Bonald, Donoso Cortes and de Maistre, who seemed to think that human beings were essentially depraved and by nature evil. The implication here is that since human beings are inherently defective, institutions like the Church or the state are necessary to establish the sacred rule of authority. Original $\sin$ in the hands of those theorists becomes the political theology that protects human beings from their worst selves, from their propensity to cruelty, malice, lust and violence. The underlying assumption here again is not the one of the classical pessimist who would lament the tendency of all human constructions to decay, fail or simply become outdated and thus clash with a reality that is constantly changing (see Dienstag, 2009b). Rather, for Schmitt, this is a situation that cannot be redeemed or put right because human nature is perceived as being ontologically tainted, inexorably infected with a propensity towards conflictuality, animosity and wickedness.

On the same note, in his latest book The Faith of the Faithless, Simon Critchley (2012: 109) talks about what he calls the 'naturalisation of original sin' by scholars, like John Gray, who lament human beings for being natural killers. A fervent critic of liberal utopianism, Gray argues that the liberal faith in progress is a secularised

\footnotetext{
${ }^{2}$ Although the diagnostic part in Lilla's and McIntyre's arguments is a fair description of the modern predicament, the implication that this is a positive thing (Lilla) or that we are condemned to choose (McIntyre) between two mutually exclusive options (Aristotle or Aquinas and Nietzsche) does not necessarily follow. On the contrary, as the subsequent analysis will show, a meeting of a certain kind of Augustinian and Nietzschean political theory might be possible.
} 
version of Christian millenarianism. To his mind, they both failed and are both dangerous because they rest on the same misguided belief in human perfectibility. Human beings, rather, are naturally drawn to the idea that life must have a meaning and are, therefore, prepared to kill for it (Gray 2007: 263). ${ }^{3}$ Gray relies on Norman Cohn's landmark study published in 1957, The Pursuit of the Millennium. Cohn's book records the detrimental influence of the millenarian impulse on the development of Western civilisation in the form of violent political utopias, such as Jacobinism, Bolshevism and Nazism, that transposed the promise of salvation from the heavenly to the terrestrial terrain. For Critchley (2102: 115), Gray represents an example of what Nietzsche would describe as 'European Buddhism' since his pessimism about the possibility of realising high human aspirations submits to a form of passive nihilism breeding resignation and escapism. The important aspect for our purposes is that this refutation of all forms of utopianism does not rely on a type of pessimism that reads human achievements as fragile and transitory because they are temporal products susceptible to historical vicissitudes and unintended consequences. Despite his powerful critique of liberal humanism, Gray's pessimism is animated by a reading of human nature that is pervaded by a transhistorical, permanent, almost metaphysical predilection to evil. Again, original sin is here read as an apriori naturalised incapacity of human beings to remedy their fate.

A similar reductionist obsession with seeing nature as something hopelessly fixed towards conflictuality, a residue of the above reified conception of original sin, is expressed in certain twentieth century attempts to explain social dynamics through evolutionary theory. In the 1970s, sociobiology emerged as an explanation of human behaviour in terms of evolved genetic predispositions. Edward O. Wilson (1975: 4), the father of sociobiology, defined it as 'the systematic study of the biological basis of all social behaviour.' Indeed sociobiology as a sub-discipline of evolutionary theory explores how the social behaviour of animals, including humans, is shaped by natural selection at the genetic level (Degler 1991; Dupré 2001). This branch of evolutionary theory has inspired some scholars of international relations to revisit classical realist arguments about human nature setting aside Waltz's concerns and investing their confidence in evolutionary science. Drawing on the wide cultural capital of biological sciences in the last half a century (Brown 1999; Bell 2006), these

\footnotetext{
${ }_{3}^{3}$ On the long and illuminating history of resembling human beings to predatory primates, or killer apes', see Haraway (1989).
} 
scholars seek to combine elements of rational choice theory with evolutionary arguments in an attempt to provide scientific evidence and intellectual legitimacy for claims that were previously considered anecdotal or impossible to ground. ${ }^{4}$

This sentiment has been expressed, perhaps in the boldest manner, by Bradley Thayer in a 2000 article in International Security. In arguing that an interpretation of evolutionary theory can strengthen the realist theory of international relations, Thayer favours a type of realism which steps away from theorising structural determinations of global anarchy and re-appreciates the role of human nature as a constant in international politics. Following Wilson's sociobiological turn and its latest incarnation in evolutionary psychology (Barkow et al 1992; Buss 2005; Pinker 2002), Thayer argues that advances in the field of sociobiology offer an opportunity for reconciliation between the natural and social sciences. In particular, Thayer suggests that evolutionary science can offer a solid scientific ground for proving the validity of two central realist themes, natural human egoism and the drive to domination providing confirmation for a bellicose human nature. His thesis rests on two major claims, both arguably underpinned by sociobiological evidence. The first argument draws directly on evolutionary theory in claiming natural selection favours egoistic individuals over altruistic ones. A member of a species is relatively 'fitter' in biological terms if it is better able to survive and reproduce than other members of the same community or species. For Thayer, this underscores the important concept of the 'survival of the fittest.' He suggests that since what is most important is relative, not absolute fitness, it is only logical to emphasise a competitive aspect to evolution within groups: 'In a hostile environment where resources are scarce and thus survival precarious, organisms typically satisfy their own physiological needs for food, shelter, and so on before assisting others' (Thayer, 2000: 131). Thayer relies here on an argument made previously by Shaw \& Wong (1987: 6) that altruism and nepotism can be explained through the concept of 'inclusive fitness' wherein natural selection favours specific genes that cause individuals to act on behalf of their gene pool (see also Dawkins 2006). Shaw \& Wong use complex mathematical experiments to construct evolutionary models of human behaviour and explain it as a result of hard-wired biological processes. The

\footnotetext{
${ }^{4}$ For an attempt to model international politics on an evolutionary paradigm, see Modelski (2008). For a sophisticated recruitment of evolutionary biology for turning IR into a process- and complexity-sensitive social science, see Bernstein et al (2000).
} 
downside here, of course, is not the inclusion of biological parameters in social explanations per se but the reduction of social behaviour to genetic processes that justify domination and hierarchy (Hawkins 1997) or the use of biology to naturalise a politically conservative perspective (see Edwards 2003).

It is not a coincidence that Thayer points to the ubiquity of hierarchical, alpha-maledominated social orders as contributing to fitness because the alternative would be perpetual conflict over resources. 'Dominance hierarchies', he argues, avoid conflict because weaker members submit resources to dominant members instead of engaging in costly conflicts (Thayer 2000: 133-4). Thayer suggests that survival in a hostile world produces a fear of ostracism and a desire for the protection of a group, and argues that conformity to a dominance hierarchy lowers conflict and keeps groups together. This, in turn, results in the clash of opposing hierarchical societies. Thayer's purpose is to show how these two arguments combined demonstrate that universal biological impulses to protect limited resources favour xenophobia and ethnocentrism making 'ethnic conflict, like war and peace...part of the fabric of international politics' (Thayer 2000: 150). In this, he follows Wilson who had argued that war as we know it is the evolutionary result of a phenomenon known as kin selection. This refers to the particular selective mechanism whereby genetic relatives affect each other's evolutionary fitness through interactions that make survival - of the relatives as well of the gene or trait encouraging such interactions - more likely (Thayer 2004). According to this logic, endemic conflict between ethnic groups can be traced back to Stone-Age adaptation processes that explain altruism and sacrifice as expressions of biological pressures for survival.

Thayer's work is symptomatic of a more or less pronounced tendency in neosociobiological circles to oversimplify the goals of evolutionary science and conflate evolutionary theory writ large with some of the most controversial aspects of sociobiology and evolutionary psychology. Apart from exaggerating the scientific consensus about neo-sociobiology within evolutionary studies, Thayer seems to have fallen victim to a functionalist explanation of social phenomena characteristic of organicist sociobiological approaches since the time of Herbert Spencer. These approaches tend to privilege 'adaptionism,' or 'the attempt to understand all physiological and behavioural traits of an organism as evolutionary adaptations' (Bell and McDonald 2001: 189). The problem is that the 'givens' of human nature 
are drawn backward from common knowledge and truths about humans in society, and the game-theory experiments which seek to prove them are often created with such assumptions in mind. These arguments are seen by their critics as politicised from the very start. Lewontin et al (1984: 264), for instance, suggest that it 'sets the stage for legitimation of things as they are.'

Indeed, the danger inherent in arguments that incorporate sociobiological arguments into examinations of modern political life is that such arguments naturalise variable behaviours, support discriminatory political structures and legitimise social and political inequalities. Even if certain behaviours have biological or evolutionary foundations, labelling those behaviours 'natural' implies that human actors are programmed to adopt set patterns of behaviour that reduce human action to a species of utility maximisation or loss aversion. While the attempt to discover a genetically determined human nature has usually been justified under the argument that knowing humankind's basic genetic make-up will help to solve pressing social problems, such a discourse about human nature seems to generate narrow visions of self-interest and self-fulfilling prophesies by putting limits on what is considered humanly possible or politically imaginable. While more sophisticated evolutionists tend to distance or guard themselves from the naturalistic fallacy, ${ }^{5}$ their 'adaptionist' approach to human nature shares a similar tendency to naturalise what is a conflictual anthropological perspective by way of conceiving it as a genetically ingrained destiny (see also Bell 2015).

\section{Free Will and Grace: original sin as theological anthropology}

What the aforementioned approaches hold in common is that they attempt to give a definitive answer to the riddle of 'what human nature really is' in order to remove the uncertainty surrounding the roots of human behaviour. In doing so, they seem to pursuit a path whereby a specific, violent and self-serving phenomenology of human action is transfigured into a biological and, therefore, unshakable ground of human nature. Although this kind of crude reductionism is rarely pronounced either in political theory, international relations or evolutionary psychology, the fact remains

\footnotetext{
${ }^{5}$ See here Rosen (2004), Johnson (2004) and Johnson \& Bering (2006). For insightful commentaries relatively well-disposed to the evolutionary turn in IR (albeit also offering cautionary notes), see Crawford (2009), Brown (2013) and Neumann (2014).
} 
that human nature is overwhelmingly interpreted as some kind of ontological 'timber' that is congenitally crooked, to paraphrase Kant. Far from constituting any proof of the empirical validity of the doctrine of original sin, such treatments of the human condition represent a fundamentally distorted and impoverished understanding of the human propensity to evil. Rather than surrendering to crude dualism, original sin as a theological concept originally developed out of Christian religious concerns with reconciling ontological monism -the idea that the world (and, within it, man as imago Deı) is created 'very good' (kala lian) (Genesis, 1:31),

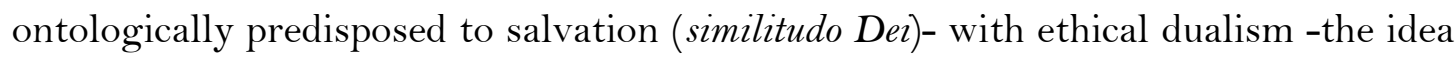
that evil (the actuality of iniquity) is introduced in the world by man's constitutive sinfulness (see Paipais 2015: 3). The latter challenge, of course is compounded by the experience of the recalcitrance of evil, i.e. the idea that evil is experienced as something that is always already there in the world even before human action, a condition Paul Ricoeur (2004: 278-9) described as the 'realism of evil'. To bring clarity to what is often an obscure debate marking the boundaries of the relationship between the voluntary and the involuntary in human nature, one has to unpack a complex story.

Original sin as a Christian doctrine did not emerge in the same form and with the same intensity on both sides of the Christian world, Eastern and Western Christianity. While some early traces of the doctrine can be located in the work of North African bishops like Tertullian and Cyprian, original sin did not take its systematic doctrinal form of inherited sin until Augustine's anti-heretic diatribes (Duffy 1988; Couenhoven 2005). What primarily concerned previous theologians, such as Tertullian, Irenaeus, Clement of Alexandria and Athanasius in East and West was the idea of the constitutive sinfulness of the human being in need of salvation by the incarnate Logos, Jesus Christ, who assumed humanity in order to enable the divinisation of human beings. ${ }^{6}$ Salvation was conceived as more than the restoration of what has been lost in the first Adam: it incorporated what had been achieved by the second Adam (ho deuteros Adam), the bridging of the gap between created and uncreated nature and the possibility of man's divinisation (not by nature but by adoption) through imitatio Christi. Clarifying, therefore, the conditions of the

\footnotetext{
${ }^{6}$ For the Greek fathers, perhaps as a critical reaction to Platonism, divinisation is not an achievement of the philosophical soul but a work of God's grace through Christ's Incarnation. In the famous words of Athanasius (On the Incarnation and Against the Arians, 8): 'The Son of God became the son of man so that humans, the children of Adam, might become children of God'.
} 
transmission and propagation of man's original corruption were not necessarily the doctrinal or pastoral priorities of those early Christian fathers. Rather their main objective seemed to be to differentiate the new faith from the fatal attraction exercised by the dominant philosophical and cosmological doctrines of the era, NeoPlatonism and Christian Gnosticism with their anti-Biblical emphasis on the soul's divine kinship and the body's inferior status, in the case of the former (see Louth 1981), and on evil as a physical reality, a cosmological principle that infects from outside, in the case of the latter (Jonas 1992). The early Church fathers were anxious to establish that salvation is not the negation of the material existence of this world (contemptus mundi) but requires conversion from sinful existence (fuga mundi as an escape from Satan's reign) (see Delumeau 1990: 11-12).

In effect, their main purpose was to reconcile the Jewish and Biblical origins of the new faith with the Hellenistic philosophical environment of late antiquity. The central issues were the scope and nature of human freedom and the degree of its dependence on divine grace for the salvation of human beings from the fatal grip of sin and death. Human beings were considered fallen, sinful, ignorant and weak by the Greek and Latin fathers of the first three Christian centuries but their emphasis was not on providing an explanation for such a plight. They rather focused on proclaiming the end of human misery through the redemptive role of Jesus Christ as judge, embodiment of divine law, and bestower of true life and union with God (see Duffy 1993: 44). In Clement of Alexandria (ca.150-215) the doctrine of an inherited sin that binds humanity in a biological solidarity in damnation is largely absent, while Irenaeus of Lyon placed sin in history and conceived of the Fall as gradual contamination with evil due to the inevitability of personal sin, not to a specific change in human nature itself (Wiley 2002: 54). How then does the doctrine of original sin find its peculiar concatenation of juridical debt and biological inheritance that is traditionally associated with? Paul Ricoeur thinks it has to be attributed to the anti-Pelagian impulse behind the motivation of Christian apologists that led to the eventual resurgence of quasi-Gnostic tendencies in the doctrine's conceptual elaboration. As he puts it, 'the concept of original sin is anti-Gnostic in its basic purpose but quasi-Gnostic in articulation' (Ricoeur 2004: 267). The central figure in whose work this apparent contradiction is vividly expressed is the father of the doctrine in its systematic form, St Augustine. 
According to the classical formulation which the bishop of Hippo bequeathed to posterity -as opposed to his earlier, and occasionally different, views on the matteroriginal sin consists of a culpable disorder of the will which caused Adam proudly to rebel against God (DCD 14.11). According to standard Christian theodicy that precludes the divine as the cause of evil, God did not create or cause this rebelliousness in man; it rather originated entirely within the voluntas of the first parent and resulted in his fall: 'For this sin, which is imputed originale, would not have existed without the work of free will, with which the first man sinned -through whom sin entered the world and passed on to all men.' (Contra Julianum Pelagianum 6.10.28, PL 44. 838). Taking the actual sin and fall of Adam literally, Augustine taught the solidarity of the entire human race in the person of the first father: when he sinned, so did all men (DCD 13.14). ${ }^{7}$ Every individual, accordingly, shares in the sinful lust of the flesh against God and against the spirit due to the sexual concupiscence in which everyone is conceived. No one escapes such concupiscence, neither the chaste and married nor the adulterous, neither baptized Christians nor infidels since the sinful essence of the concupiscence itself determines the nature of the offspring thereby conceived (De nuptiis et concupiscentia 2. 21.36). Therefore, no one that is born of that union which cannot be completed without shameful lust is free of $\sin$.

Despite false impressions that Augustine is here advocating a Platonic diminution of the body, the root of primal sin is not carnal desire but the unruly state of the soul. Augustine argues that disobeying a direct command from God when life was so blessed would be thinkable only for those who had already begun to be proud in their inner hearts (Gn.Litt. XI. 30.39; C.Jul.imp. I.71). Eating the fruit, then, was merely the external manifestation of an evil will prior to the evil act. And yet, if life in Paradise was so idyllic whence this evil will? Augustine admits here of the deeply irrational character of primal sin: instead of an efficient cause, Augustine writes with rhetorical flair, sin has a 'deficient' cause (DCD 12.6, 7, 9). Yet, the primal sin was so great that there was a radical change for the worse in Adam's nature, and thereby in

\footnotetext{
7 The argument of Augustine's mistranslation of Romans (5:12) is widely accepted in patristic studies. In his anti-Pelagian fervour Augustine, who could not read Greek, used Ambrosiaster's Latin Vulgate

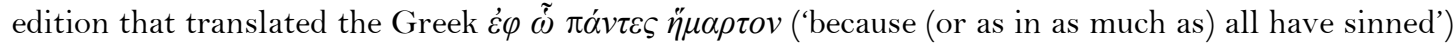
as in quo ('in whom all have sinned'). Instead of grounding human solidarity in sin through inclusion in Adam's loins, the original Greek focused more on contrasting Adam's deed that brought death into the world with life now offered in Christ.
} 
the nature of the entire human race (De nupt.et conc. I.32.37). And yet, this connection between primal sin and personal sin was made by earlier Christian fathers as well without, however, this committing them to a doctrine of original sin as inherited corruption. Theophilus of Antioch, Justin Martyr and Irenaeus all affirmed man's inclination to evil, yet for them human beings fall into personal sins as they grow up because Adam's sin weakened his progeny and exposed them to temptation. Augustine, however, pursues a more radical view, arguing against the Pelagians that infants need to be healed by Christ, not because of their potential to sin, but because they have inherited original sin. Obviously, such a position gives rise to problems. Augustine appears to undermine his own anthropological explanation of evil, when to counter the Pelagian excesses he concedes that $\sin$ is a hereditary taint congenitally transmitted.

For Duffy (1988: 607) and Ricoeur (2004: 273-4) the apparent contradiction between responsibility and inevitability appears largely due to Augustine's mixture of categories: a juridical category of debt, which concerns deliberate and therefore punishable acts, and a biological category of inheritance, which concerns species unity through propagation. Augustine directed the juridical category against the Manichaeans, as he insisted on the separation of the beginning of creation from the beginning of evil; and the biological category against the Pelagians, as he insisted on a pre-volitional solidarity in evil grounded in procreation, which, of course, resonates with Platonic tendencies to incriminate bodily existence. The latter transmuted the Hebraic experience of Israel's captivity under sin grounded on an interpretation of sin as a collective or corporate act (Cantley 2012) into sin as a hereditary vice carried by every individual by way of its participation in Adam's seed. Thus the doctrine appeared incoherent, though its central insight -that the bondage of the heart to evil is self-imposed and that freedom and inevitability, individuality and solidarity are paradoxically related rather than starkly contradictory- is profound. Eventually, the stock explanation of inherited guilt and corruption resulting from the inclusion of all of us in Adam's loins made the classical doctrine hard to distinguish from its Gnostic rival, for $\sin$ appeared as an intrinsic and inescapable dimension of the human condition for which no one is or can be liable (see also Forsyth 1987).

That said, Ricoeur insists that there is a deeper insight revealed in Augustine's weaving together of the juridical category of imputation and the procreational 
category of inheritance. Augustine's concerns remain soteriological aiming at grounding God's work of salvation on his gratuitous offering of the gift of grace (Bonner 1993: 84-89). This step is taken in his meditation on Romans 9:10-29 where the attention is no longer Romans 5 and the opposition of two figures, Adam and Christ, but God's arbitrary conferral of His favour: 'I loved Jacob and I hated Esau'. To justify the act of Esau's condemnation, Augustine has to shore up the justice of Jacob's election, so Esau must be conceived as carrying the guilt even before his birth. The justice of the one's election demands the symmetry of the other's reprobation (Ricoeur 2004: 275). Even if, strictly speaking, Augustine's teaching of predestination may sound hopelessly Gnostic, it still remains faithful to the mystery of evil; the fact that evil is there even before we choose it and that we stand almost impotent to eradicate it because it resides in the darkest involuntary of the human heart. Augustine's youthful insight that nusquam nisi in voluntate esse peccatus remains true and firmly anti-Gnostic but his own experience of the obstinacy and irreducibility of evil drives him to a soteriology that threatens human freedom and revives the persistent Neoplatonic and Christian Gnostic elements in his thought: the association of sin with sexuality (concupiscence ambiguously identified with carnal desire) and the insistence on a form of knowledge (gnosis) that in order to serve theodicy may entail a demoralising fatalism (Duffy 1993: 106-15).

\section{Freedom, necessity and hope: original sin as philosophical anthropology}

If Augustine's anti-Pelagian militancy towards the end of his life led him to a dangerous proximity with the Gnostic dogmas of his youth, the legacy of the doctrine he bequeathed, and whose emblematic formulation he was responsible for, was marked by the implications of his assertion that Adam and Eve's sinful transgression in paradise descends to all subsequent human generations as a literal inheritance. ${ }^{8}$ Central to the modern criticism of Augustine's description of sin as a literal inheritance has been a key distinction between nature and history; between birth as a quintessentially involuntary and generically animal event, and culture as a distinctively human realm of free and rational activity. Birth, in this view, represents a kind of pole in the progress of the individual from unreasoning slavish immersion

\footnotetext{
8 The transition from a concern with original sin as the general situation of mankind to that of the relationship between the sin of Adam (peccatum originale originans) and the sin of humankind (peccatum originale originatum) that attracted so much opprobrium from modern thinkers is usually considered intensified and solidified in post-Tridentine theology (see Wiley 2002: 91 and Sesboüe 2004: 15).
} 
in the processes of nature (necessity), to identity as a fully individuated, fully human, fully rational being (freedom).

Arguably, the seminal roots of this division between an inert nature and a controlling human will as the source of personhood can be traced in Augustine's doctrine of the will (McFarland 2010: 75-79). ${ }^{9}$ Whereas in his anti-Pelagian treatises Augustine seems to defend an overbearing conception of grace phenomenally in opposition to human freedom, what he is really rejecting is the Pelagian understanding of the will as a power of choice, as a controlling centre of personhood presiding over a detached human nature which it rules. Augustine insists that by separating the will from nature and making it a source of action over and above the nature in which it is found, his Pelagian opponents, such as Julian of Eclanum, render willing not an expression of one's nature -as it is held in the patristic tradition from Gregory of Nyssa to Maximus the Confessor- but a kind of unaccounted force operating independently of it (see Mühlenberg 1993: 109-12). And yet, although Augustine's mature theory of the will rejects the Pelagian autonomisation of the will, his entanglement with the Pelagian controversy eventually caused an imperceptible displacement of his position. In refining his account of the relationship between post-lapsarian will and concupiscence, he raises the possibility of a split within the self whereby the 'I' who unwillingly covets sinful acts is distinct from the 'I' who wills to obey God's law. Augustine's inaugural gesture can be seen as setting in motion a long process that eventually led to the disjuncture between a rational human will, obeying God's commands, and a 'gnomic will' that reflects the human capacity to choose (see also Taylor 1989). As a result, human willing assumed the status of an independent capacity of human beings to distinguish themselves from their nature, whereby the latter is reduced to an ontological reservoir of passions, drives and other rampant desires that the operation of the will is there to control (rational will) or abide by (gnomic will).

One of the Augustinian masters of twelfth-century theology whose Sententiae became a degree requirement for medieval doctors of theology (McCord Adams 1999: 18), Peter Lombard, reflects this growing distinction in his Christology. Lombard drives

\footnotetext{
9 The analysis in this paragraph draws on McFarland's excellent book on original sin and his juxtaposition of Augustine's and Maximus the Confessor's outlooks on the relationship between human nature and will.
} 
a wedge between personhood and human nature in his effort to defend the reality of Christ's humanity. He argues that Christ's person could not sin since, in its hypostatic union with the Divine Word, the former is God eternally and necessarily. However, he adds, if Christ's human nature were not united to the Divine Logos, it could sin like any other human nature. Here human nature is already considered capable of sinning apart from its hypostatic expression in human will. This gradual autonomisation of nature (with will as its controlling centre) in Lombard's distinction between Christ's person and Christ's human nature is further confirmed in his subsequent separation of rational (affectus rationis) from sensory affections (affectus sensualitas) in the constitution of the human will itself (McCord Adams 1999: 23-4). In that way, a division is established within the human will between rational and sensual human emotions with the former reflecting the true self's coercive authority over the latter's unruly tendencies. The will is no longer the $\tau \rho o ́ \pi o \varsigma$ $\dot{v} \pi \alpha \dot{\alpha} \xi \varepsilon \omega \varsigma$ (way of existence) of a specific nature but the controlling master of an inert and inherently rebellious nature. It is exactly this understanding of the relationship between human nature and will that lies behind Lombard's denial that Christ merited a passible human nature: Christ, he insists, was not subject to its changes necessarily, but only voluntarily for our sake. Even though Lombard's intentions are perfectly orthodox in trying to show that Christ assumed a real as opposed to a phantom body, capable of experiencing the sufferings of mortal flesh (pain, hunger, death), and a real soul capable of experiencing real emotions (sorrow, stress, fear), he still seems to assume that passibility is a mark of our fallen nature rather than of our creaturliness. Lombard seems here to miss the patristic lesson that it is not human suffering and passibility as such that causes distress but only our sinful disposition to it (our resulting unhappiness out of guilt).

Albert Hirschman's (1977) The Passions and The Interests was pivotal in demonstrating how this sensibility that separated human nature from will and reduced human passions to expressions of unruly vices in need of control and repression, was a central motif in early modern thought encountered in thinkers such as Machiavelli, Hobbes, Spinoza and Hume. The idea of rational interests as countervailing passions that would suppress and harness 'man's evil impulses' (Hirschman, 1977, 30) appears as the next stage in the story of the separation of a rational enlightened will from an evil nature that reveals 'what man really is'. The 
subsequent typically Enlightenment narrative of the priority of the morally responsible individual that remains accountable despite her occasional relapses, and only to the extent that her actions can be recognised as voluntary, developed in opposition to any subordination to blind necessity or involuntary impulses deriving from human nature. In fact, only the former was recognised as the expression of true personal identity and the source of moral autonomy and accountability. Within that model, criticisms of an inheritable original sin have always been implicitly, and often explicitly, part of a broader argument concerning the justice of God's providence and the carving out of space for human freedom within a framework of modern theodicy that rejects natural determinism grounded on human nature or natural evil (see Jeffery 2008). Even admitting that such a thing as inheritable sin were possible, a good God, a God whose justice is commensurate with the expectations of autonomous moral reason, would not, indeed could not, punish the heirs of Adam and Eve for a sin they did not themselves voluntarily commit.

This modern consensus on the limits of responsible interpretation of the doctrine of original sin has been most representatively exemplified in the work of the enlightener par excellence, Immanuel Kant. The idea he defended is that inheritable sin cannot be reconciled with the necessarily voluntary and individual conditions of just moral accountability, and so must be excised from any account of the enduring truth of the doctrine. Otherwise, the possibility of meaningful and just moral accountability is undermined and obscured. For this reason, in his solution to the problem of evil caused by $\sin$ as posed by the traditional formula, the opposition between the natural and the rational, between birth as an event marked by total immersion in natural processes, and reason as a realm of unconditioned free activity, reaches a remarkable extreme. Of the notion of the literal inheritance of sin, Kant remarks with disdain:

Whatever, the nature, however, of the origin of moral evil in human being, of all the ways of representing its spread and propagation through the members of our species and in all generations, the most inappropriate is surely to imagine it as having come to us by way of inheritance from our first parents. (Kant 1998: 62)

Kant objects so strenuously to the description of sin as an inheritance because it so obviously, in his view, confuses the realms of the voluntary and the involuntary; 
because justice in moral attribution depends, above all else, on clarifying the distinction between these two realms. To this end, Kant posits an extraordinary disjunction between the temporal and the transcendent as integral to human moral identity. To his mind, the ineptitude of the traditional formulation of the doctrine is its failure to appreciate the inscrutable mystery of the transcendence of human freedom. Utterly unconditioned volition alone, Kant emphatically explains, is the measure of justice in attribution:

\begin{abstract}
Moreover, to have the one [i.e. good] or the other [i.e. evil] disposition by nature as an innate characteristic does not mean here that the disposition has not been earned by the human being who harbors it, i.e. that he is not its author of it, but means rather that it has not been earned in time (that he has been the one way or the other always, from his youth on). The disposition, i.e. the first subjective ground of the adoption of the maxims, can only be a single one, and it applies to the entire use of freedom universally. This disposition too, however, must be adopted by the free power of choice, for otherwise it could not be imputed. (Kant 1998: 50)
\end{abstract}

So Kant refuses to accept that we stand at an equal distance from nature and reason. Our 'propensity to evil' (Hang zum Bösen) cannot be attributed to our biological or psychological nature but it is something brought upon us by ourselves. As Kant (1998: 56) puts it, there is a 'radical innate evil in human nature'. At first glance, the claim that there is an intrinsic taint in human volition seems to contradict Kant's emphasis on the priority of human autonomy -a philosophical idea Kant served all his life- as it might suggest that when we act immorally we can't be held responsible because we don't act as free moral agents (Kant 1998: 62). Kant's solves the paradox by bringing into full conceptual fruition a distinction that has been in gestation long before him, that one between 'will' (Wille) in the sense of our rational moral capacity to obey the categorical imperative and 'will' (Willkür) as the expression of our power of choice (see Dews 2013: 23). By doing so, Kant hopes to eschew the implication that our debility or perversion of the will is part of our natural endowment -despite the fact that we are forced to accept it 'as if it is natural (Kant 1998: 57-8). Such a conclusion would revive the possibility that the tendency to violate the moral law is inescapable and thus would resurrect the danger of freedom submitting to natural determinism that the distinction between Wille and Willkür sought to unravel in the first place. 
And yet, Kant is arguably confronted with an impossible conundrum. On the one hand, he is keen to puncture contemporary illusions about an innocent 'state of nature' inducing human beings to a perpetual course 'from bad to better' (Kant 1998: 45). On the other hand, he wants to escape the implication that human beings are equally caught in a Manichean struggle between natural desires and the constraints of morality. Like in Augustine, evil is real but it does not have substance, rather it finds its origin in perverse human will. However, if the human power of choice towards evil is powerful and pervasive as to be tantamount to something inborn, how can the portrayal of evil as freely chosen be sustained? If evil is indeed ineluctable as 'the multiple of woeful examples that the experience of human deeds parades before us' (Kant 1998: 56), how can the vision of man's moral autonomy be vindicated or, even more so, how can a being corrupted at its root repair the damage solely through an act of the same will? (Kant 1998: 38) Eventually, caught in a bind between freedom and necessity, Kant finds himself compelled to concede that conversion to morality is a Herculean task that justifies the idea of a supersensible postulate. In a telling analogy to Augustine's reference to man's spontaneous conversion through the gift of grace which is the work of God's love, Kant seems here to allow a role for divine grace. Allen Wood (1970) has even regarded it as Kant's 'fourth postulate'. The problem with such a concession however is that such an explicitly religious concept does not chime very well with Kant's insistence on the priority on human autonomy and the unaided character of human freedom. In all earnest, Kant (1998: 183-4) is essentially trying to square the circle when he states that there are no other means for a human being to become worthy of divine assistance:

Except the earnest endeavour to improve his moral nature in all possible ways, thereby making himself capable of receiving a nature fully fit -as it is not in his power- for divine approval, since the expected divine assistance itself has only his morality for its aim.

In effect, Kant here proposes a mystery as solution to a puzzle. It appears that the only possible way to reconcile the fact of sin with the rational conditions of moral accountability is to posit a profound disjunction at the core of human identity. As solution to the problem of justice in accountability posed by the traditional 
formulation of the doctrine of original sin, Kant's proposal is formidable, but also symptomatic of any attempt to investigate the meaningfulness of the doctrine 'within the boundaries of mere reason': better to imagine the will in such metaphysical isolation, than allow that God would ever impute sin to a person where rational criteria of accountability do not hold; better to imagine the self as unconditioned rational will, transcending even the event of one's own birth, than allow the injustice of imputing sin where such will is not present.

\section{Finitude and original sin: nuancing human nature}

As it seems, both theological and philosophical anthropologies of 'man's innate propensity to evil' are overdetermined by the priorities of some form of theodicy or apologetics, Christian or humanist. The reality and intractability of evil is taken seriously but, to avoid laying the blame at God's doorstep or denying man's rational nature, a complex dialectics of freedom (voluntas in Augustine, rational will (Wille) in Kant) and hope (grace and predestination in Augustine, grace and providence in Kant) is offered in place of the acceptance of evil as a cosmological or philosophical first principle. What is, however, imperceptibly conceded in both cases is the unexamined designation of meaningless suffering as an evil in need of justification. What this 'naturalisation' of suffering accomplishes is an unquestioned equation of evil and human finitude to the extent that suffering cannot be accepted as the fate of human beings' mortal and created nature but has to be explained away as part of a general scheme of things that justifies it. The key to unpacking the secular and theological theodicies behind the problem of evil's origin and nature, then, is to understand its reliance on an understanding of suffering as meaningless and, therefore, in need of justification. This is the true meaning of Nietzsche's aphorism that it is the 'meaninglessness of suffering, not suffering as such, [that] was the curse that lay over mankind so far' (Nietzsche 1967: 162). The upshot here is not that suffering as such is suffering devoid of valuation but rather that the experience of suffering should be open to value ascriptions and attitudinal dispositions. Taking meaningless suffering to be apriori evil presupposes that 'suffering as evil' is accepted as an ontological given of the human condition which then authorises the need for its 
justification. ${ }^{10}$ What this understanding of the human condition forecloses is the possibility to read suffering not as evil but as part of the facticity of human finitude open to meaning imputation. ${ }^{11}$

In Augustine, this tendency is expressed in his conflation of the nothingness of man's evil inclination (defectus) with the biblical nothingness of the creation of the world from nothing (creatio ex nihilo). Augustine's Neoplatonic prejudices do not really make it easy for him to sustain the difference separating the nothing of creation (finitude) from the nothing of deficiency (sin). The anti-Pelagian controversy only helped to accentuate this conflation by posing a corrupted nature carrying a hereditary vice in stark parallel to the positivity of evil in the Gnostic myth. On the other hand, in Kant's anthropology, evil's recalcitrance is registered as man's innate propensity to evil but finitude (man's limitations as a created being) is never seriously taken into account. The individual's rational nature is outside history which means that there is no real risk involved in the journey of the realisation of human freedom. To be sure, history's vicissitudes and contingencies are recognised but only as part of Nature's hidden plan leading to an ever perfect world (Kant 1991). Kant's philosophy of history explains how the human fall into evil proves ultimately beneficial by providing the motor for advance towards the full institutionalisation of freedom (Dews 2013: 36). The contradiction of man's finiteness and freedom is glossed over in Kant because he has skilfully taken real human beings out of the equation and has replaced them with the image of rational humanity struggling against its evil inclinations (Molloy 2013). However, it is exactly such a move that pits human beings against their nature as Kant's seems to be contrasting the epoch of nature which is led by private vices and the pursuit of self-interest with the epoch of freedom which will inevitably follow once humanity overcomes its self-imposed alienation (Wood 1999: 296). The barriers separating human finitude from human vice are again dangerously blurred.

\footnotetext{
${ }_{10}$ The Book of Job stands as the opposite example wherein a just man is overwhelmed by suffering with no apparent justification. See also the Johannine account of Jesus' encounter with the man born blind in which He refuses to associate the man's misfortune with his sins or the sins of his parents (John, 9:1-4) or the story of the victims of the tower of Siloam and that of the Galileans massacred by Pilate (Luke 13:2-6). For the Christian narrative such confusion between guilt, death and suffering is characteristic of the demonic capacity of sin to conceal its binding power.

${ }^{11}$ For an excellent analysis of how the Christian doctrine of creation from nothing undermines the equation of suffering, pain and the apparently pointless destruction of creatures through natural disasters or the struggle for survival with evil, see McFarland (2014: 77-8, 129-31). McFarland convincingly argues that the unity of creation 'groaning in labour pains' is a corollary of the belief in one God who creates from nothing rather than an empirical judgement.
} 
Given the intricacies of the matter, it is not a coincidence that among the IR Augustinian realists it is a theologian, Reinhold Niebuhr, who possessed the theological skills to discern its implications. An excellent theologian despite his own doubts (see Gilkey 2001), Niebuhr (1953) consciously resists this imperceptible conflation of createdness and sinful existence and, instead, calls for what he dubs 'modified Augustinianism'. Niebuhr (1941: 178) explicitly argues that the Christian doctrine of original sin rests on a particular interpretation of 'the contradiction of [man's] finiteness and freedom.' This is hardly surprising given that attentiveness to the perils of exercising freedom under the conditions of finitude was perhaps his most consistently dwelled upon concern. By emphasizing the temptation that precedes sin -that there is a situation or context for it- Niebuhr (1941: 244) was attempting to hold two positions in tension with one another: the inevitability of sin and man's responsibility for it. Indeed, Niebuhr was critical of Calvin and especially Luther for denying free will 'to the point of offering man an excuse for his sin'. And so, similarly, Niebuhr (1935: 55) was a persistent dissenter from the notion that original sin is an inherited corruption, because 'its inheritance destroys the freedom and therefore the responsibility which is basic to the conception of sin'. Following Kierkegaard, Niebuhr insisted that sin posited itself, but does not have an actual history of origins. To give evil a history is to evade responsibility for it, to passively consign not just its origins, but the burden of accountability for it, to some juncture in the distant past. This does not mean that the sin of past generations does not weigh on contemporary men but, here, Niebuhr is closer to the Hebraic biblical tradition of corporate $\sin$ as captivity (Israel's Babylonian experience) than the Augustinian notion of hereditary taint.

Niebuhr argues, then, that the temptation to sin, though not sin itself, is always before us in the situation of our finitude and freedom, with the notion of temptation symbolised in the presence of Satan in the Garden of Eden. For Niebuhr, the importance of Satan, the serpent as the agent of temptation, was that it preserved the basic integrity of the human situation in the sense that sin was not merely due to man's finitude -to be finite is not to be evil: 'The devil fell before man fell, which is to say that man's rebellion against God is not an act of sheer perversity, nor does it follow inevitably from the situation in which he stands' (Niebuhr 1941: 180). There is an evil antecedent to any evil human action; temptation must intervene before our 
situation gives rise to sin. We do sin inevitably, but not directly because of our situation of dwelling at the juncture of nature and spirit. That finitude and freedom, for Niebuhr, are the two elements of man's situation means that man is peculiarly aware of his finitude not as a necessity ontologically opposed to his freedom but as an opportunity or condition of possibility to orient his existence towards God (or not). The looming temptation is to see our finitude not as a condition of possibility (limitation) for our freedom but as an impediment (limit) to our freedom and capitulate to its necessity (see Paipais 2013: 857).

The upshot here is that Niebuhr wishes to avoid an ontological dualism whereby man, simply by being involved in the flux of nature and having a particular body and being bound to time and place, is sinful. Indeed, Niebuhr thinks we are both our genetic impulses and our ability to transcend them but the two do not constitute the human being as a two-layer composite. True to the Christian anthropology of man as imago Dei, Niebuhr rejects a facile nature/spirit dualism or an existential superimposition of 'spirit' over 'nature'. Without denying its genetic make-up, he views the human being as an ongoing spiritual project where integration into the realm of mind and spirit transforms all biological elements constituting the human person' (Duffy 2005: 219). Human nature is not our genetic imprints in isolation but the way mind and will repress, redirect and sublimate them into actions and choices that set humans apart from other animals. Evil, greed and violence then are not direct results of intractable genetic impulses towards selfishness as some neosociobiologists would have it (Dawkins 2006, 1982) but complex bio-cultural configurations that merely reflect the destructive (evil/sinful) capacity of human beings to be held captive by their own incarnate desires (see Mulhall 2005: 84). Yet the latter, far from being the result of a stubbornly recalcitrant nature, constitutes an expression of our nature as unruly drive for domination that manipulates both biology and environment. In its restless transcendence, the human animal can defy both blind nature and reason's prudence. Therein lies the source of human beings' both tragedy and magnificence (Niebuhr 1941: 122).

Even if Niebuhr's formulations may not always escape the entrenched vestiges of an inert natura pura, his lesson is that we do not need to naturalise evil or man's propensity to wrong-doing to take demonic or bellicose tendencies in man seriously. Evil's intractability is always already there not because we are condemned to be evil 
but because we are condemned to be free (freedom here meaning not freedom from our nature but freedom from the security-seeking impulses stemming from our finiteness). The question remains, however, whether Niebuhr's theological anthropology, in trying to escape false historicism or integralism (an uncritical recourse to Scripture and/or tradition), accords proper significance to the sacramental or eschatological approach to original sin that puts anthropology on an equal footing with Christology. What is at stake here is not whether Niebuhr strays from Christian orthodoxy but whether a proper understanding of original sin requires placing it within the parameters of the operation of grace through Christ's work of salvation. In essence, the real question emerging is whether the classical theme of original sin is only open to the experience of faith with Christ and whether this experience can escape the epistemological monopoly of Christian apologetics or ‘political Augustinianism’ with its fatalistic implications.

Sensitive to this dimension, Ricoeur builds on St. Paul's (Romans 5: 12-21) figurative interpretation of Adam as Christ's antitype to expose the structure of hope at the heart of the symbol of original sin (see also Delumeau 1990: 247). Ricoeur (2004: 279, 282) shows how the 'absurd concept' of original sin stands for an anthropology posed by default (without an objective content), drawing on the one hand on the experience of regeneration achieved in Christ and, on the other hand, on the universalisation to all humankind (the original Adam) of the experience of salvation had by the Israelites. Freed from theodical (to salvage God) or rationalist (to salvage human reason) priorities, original sin tells the story of human nature as an ongoing project manifesting the paradoxical structure of hope: 'as if in an unfathomable depth dimension, at the core of the disposition towards the good, one could no longer distinguish between the identity of human effort and the gift of another' (Ricoeur cf. Theobald 2004: 122). ${ }^{12}$ The paradox of human freedom and evil's inevitability is here highlighted under the messianic mystery of trust in Christ's regenerative power. God's silence or hiddenness and Christ's weak messianic power are signs of love and respect for human freedom and a way of healing the evils of this world through His absolute trust to His creation. Christ's agapaic vulnerability becomes a therapeutic

\footnotetext{
${ }^{12}$ It is here that Christian soteriology meets with the Nietzschean heterodox project in saving us from an essentialist conception of ourselves as fixed or innately perverse. As Nietzsche's aim is to open up the possibility of our existing otherwise, so too the doctrine of original sin already incorporates this dimension: 'in showing us to be originally sinful, Christ simultaneously shows that our sinful nature can be overcome or reborn, and hence reveals our fallenness as contingent, as no longer necessary’. (Mulhall 2005: 44)
} 
resistance to the evil generated by human freedom that, at the same time, operates as an affirmation of the forces of resistance inherent in the world since its creation. Human beings discover that the gift of creation, including human nature, despite all negative experiences, is 'no 'poisoned chalice' but, in fact, contains the possibility for the healing of life that has been destroyed' (Theobald 2004: 132).

\section{Conclusion}

The doctrine of original sin in its original formulation rested on a complex dialectics of will and grace itself obeying the priorities of Christian theodicy and apologetics. Inherently unstable, as it tried to reconcile two contradictory experiences -i.e. the recalcitrance of evil in the world and man's responsibility for it (sin)-, it was subsequently appropriated by modern philosophical anthropology itself struggling to define the relationship between human freedom, necessity and hope. If its theological expression cannot be understood apart from its soteriological context, its philosophical reformulation equally obeyed the priorities of Enlightenment philosophies of history akin to secular eschatologies (Löwith 1949). Both theological and philosophical anthropologies share an interest in rationalising (and therefore mythologising) a concept that was rather meant to express humankind's paradoxical condition as both free and bounded. In that sense, any attempt to wrest the concept of original sin of its complexity and semantic surplus is bound to trivialise it or render it 'false knowledge' as human beings' creaturely, rather than ethical, inability to overcome innate imperfection. Original sin should rather be read as a symbol of an irreducible tension within human nature between transcendence and immanence, freedom and necessity, hope and mundaneness. Such an understanding refuses to reduce the paradox of original sin to the parody of man's evil nature.

International Relations stand only to benefit from a political theological account of the origins of man's conflictual tendencies given the stakes involved in such an enrichment of our theoretical and political imagination. I have shown that it is crucial to revisit the fragmented theological tropes behind contemporary anthropologies and concomitant philosophies of history precisely because these tropes are not readily legible as theological anymore. On the one hand, mainstream realist and liberal accounts of the causes of war are plagued by a secularised, yet diluted, theological anthropology that authorises the mythic politics of 
sovereignty/security as protection from a Hobbesian 'state of nature'. Indeed, the entire modern paradigm of security is premised on a Schmittian conception of politics as the reproduction of enmity and the regulation of insecurity that scholars like Brad Evans (2013) have aptly called 'liberal terror'. On the other hand, the recent turn to sociobiology and evolutionary psychology in IR is promising to the extent that age-old dualisms, such as mind/body and nature/culture, are put to scrutiny and deconstructed to reveal the dynamic nature of human action and motivation. However, residues of a resurrected reductionism and a biological determinism of sorts have not disappeared. The temptation to see human nature as aggressive, rapacious and indelibly prone to violence or resort to sociobiological explanations that operate as scientific confirmation of anthropological pessimism and authorize the techniques of the modern liberal apparatus of biopolitical security remains persistent.

In contrast, understanding that the source of evil lies not in man's natural wickedness but in man's freedom permits two paradoxically inseparable insights: the root cause of human troubles is not our mortality, finitude, materiality or biological make-up but our search for security from the contingencies of our natural condition, finitude. That said, the second valuable insight is that realising that we are the authors of our sufferings may demystify the source of evil in the world but does not explain its recalcitrance and inevitability away. And yet, evil may be inevitable but it's not necessary. Human nature is not condemned to be evil; it is rather condemned to be free to either embrace creation, with all its fragility, as a gift and a promise (belief) or seek a self-defeating flight from insufferable vulnerability (unbelief). Original sin stands as the symbol of that predicament which is at the same time the condition of possibility for the exercise of human freedom, responsibility and judgement. A political theological reading of human nature, then, uncovers the surplus semantic potential enclosed in a concept such original sin and offers a richer conception of human nature beyond the confines of anthropological pessimism and/or evolutionary naturalism. In this outlook, pace Wight (1948: 33), hope is properly recognised, not as an otherworldly theological virtue or the prospect of an abstract utopia in the future, but as the messianic counterpart to original sin echoing the patristic lesson that the enigma of human nature can only be illumined from the eschatological perspective of redemption as an ever-present historical possibility through the therapeutic practice of love. 


\section{REFERENCES}

Adams, Marilyn McCord (1999), What Sort of Human Nature? Medieval Philosophy and the Systematics of Christology, Milwaukee: Marquette University Press.

Barkow H. Jerome, Cosmides Leda and Tooby John, eds. (1992) The Adapted Mind: evolutionary psychology and the generation of culture, Oxford: Oxford University Press.

Bell, Duncan (2015), 'In Biology We Trust: Biopolitical Science and the Elusive Self in Daniel Jacobi and Annette Freiberg-Inan eds., Human beings in International Relations, Cambridge: Cambridge University Press.

Bell, Duncan (2006), 'Beware of false prophets: biology, human nature and the future of International Relations theory', International Affairs 82(3): 493-510.

Bell, S. A. Duncan, MacDonald, K. Paul and Thayer, A. Bradley (2001), 'Correspondence: Start the Evolution Without Us', International Security, 26(1): 18798.

Bernstein Steven, Lebow Ned Richard, Stein Gross Janice and Weber Steven (2000), 'God Gave Physics the Easy Problems: adapting social science to an unpredictable world', European Journal of International Relations, 6(1): 43-76.

Bonner, Gerald (1993), 'Augustine's Doctrine of Man: image of God and sinner', in Everett Ferguson ed., Studies in Early Christianity: a collection of scholarly essays, New York and London: Garland Publishing.

Brown, Andrew (1999), The Darwin Wars: how selfish genes became stupid gods, London: Simon \& Schuster.

Brown, Chris (2013), "Human nature', science and international political theory', Journal of International Relations and Development, 16: 435-454.

Brown, Chris (2005), Understanding International Relations, $3^{\text {rd }}$ ed. Basingstoke: Palgrave Macmillan.

Burchill, Scott et al eds. (2009), Theories of International Relations, $4^{\text {th }}$ ed. Basingstoke: Palgrave Macmillan.

Buss, David ed. (2005), The Handbook of Evolutionary Psychology, New York: Wiley.

Cantley, J. Michael (2012), 'The Biblical Doctrine of Original Sin', Proceedings of the Catholic Theological Society of America, http://ejournals.bc.edu/ojs/index.php/ctsa/article/view/2626

Couenhoven, Jesse (2005), 'St Augustine's Doctrine of Original Sin', Augustinian Studies 36(2): 359-396. 
Crawford, C. Neta (2009), 'Human Nature and World Politics: Rethinking 'Man', International Relations 23(2): 271-288.

Critchley, Simon (2012) The Faith of the Faithless: Experiments in Political Theology, London; New York, Verso.

Dawkins, Richard (2006), The Selfish Gene, 3rd edition, Oxford, Oxford University Press.

Dawkins, Richard (1982), The Extended Phenotype: the long reach of the gene, Oxford: Oxford University Press.

Degler, N. Carl (1991), In Search of Human Nature: The decline and revival of Darwinism in American social thought, New York; Oxford: Oxford University Press.

Delumeau, Jean (1990), Sin and Fear: the emergence of a western guilt culture, $13^{\text {th }}-18^{\text {th }}$ centuries, trans. Eric Nicholson, New York: St Martin's Press.

Dews, Peter (2013), The Idea of Evil, Chichester: Wiley-Blackwell.

Dienstag, F. Joshua (2009a), 'Pessimistic Realism and Realistic Pessimism' in D. Bell (ed.), Political Thought and International Relations: variations on a realist theme, 159-176, Oxford, N.Y.: Oxford University Press.

Dienstag, F. Joshua (2009b), Pessimism: Philosophy, Ethic, Spirit, Princeton University Press.

Donnelly, Jack (2000). Realism and International Relations, Cambridge: Cambridge University Press.

Duffy, J. Stephen (2005), 'Genes, Original Sin and the Human Proclivity to Evil', Horizons, 32(2): 210-34.

Duffy, J. Stephen (1993), The Dynamics of Grace: perspectives in theological anthropology, Collegeville, Minn.: The Liturgical Press.

Duffy, J. Stephen (1988), 'Our Heart of Darkness: original sin revisited', Theological Studies 49: 597-622.

Dupré, John (2001), Human Nature and the Limits of Science, Oxford: Oxford University Press.

Edwards, Jason (2003), 'Evolutionary Psychology and Politics', Economy and Society 12(2): 280-98.

Elshtain, Jean-Bethke (2008), Sovereignty: God, State and Self, New York: Basic Books.

Evans, Brad (2013), Liberal Terror, Cambridge: Polity Press.

Forsyth, Neil (1987), The Old Enemy: Satan and the combat myth, Princeton, New Jersey: Princeton University Press. 
Freyberg-Inan, Annette (2004), What Moves Man: The Realist Theory of International Relations and Its Judgment of Human Nature, New York: SUNY Press.

Gilkey, Langdon (2001), On Niebuhr: A Theological Study, Chicago: Chicago University Press.

Gillespie, Allan (2009), The Theological Origins of Modernity, Chicago and London: The University of Chicago Press.

Gray, John (2007), Black Mass: Apocalyptic Religion and the Death of Utopia, New York: Farrar, Straus and Giroux.

Haraway, Donna (1989), Primate Visions: Gender, Race and Nature in the world of modern science, New York: Routledge.

Hawkins, Mike (1997), Social Darwinism in European and American Thought, 18601945, Cambridge: Cambridge University Press.

Hirschman O. Albert (1977), The Passions and the Interests: Political Arguments For Capitalism Before Its Triumph, Princeton, NJ: Princeton University Press.

Jeffery, Renee (2008), Evil and International Relations, New York: Palgrave.

Johnson, Dominic (2004), Overconfidence and War: The havoc and glory of positive illusions, Cambridge, Mass.: Harvard University Press.

Johnson, Dominic and Bering, Jesse (2006), 'Hand of God, Mind of Man: Punishment and Cognition in the Evolution of Cooperation', Evolutionary Psychology, human-nature.com/ep. 4: 219-233.

Jonas, Hans (1992), The Gnostic Religion: the message of the alien God and the beginnings of Christianity, London: Routledge.

Kant, Immanuel (1998), Religion within the Boundaries of Mere Reason and Other Writings, trans. Allen Wood and George Di Giovanni, Cambridge: Cambridge University Press.

Kant, Immanuel (1991), 'Idea For A Universal History With A Cosmopolitan Purpose' in Reiss, H. S., Kant, Cambridge Texts in the History of Political Thought (2nd ed.), 41-53, Cambridge: Cambridge University Press.

Lewontin, R. C., Rose Steven, and Kamin, J. Leon (1984), Not in Our Genes: Biology, Ideology and Human Nature, New York: Pantheon Books.

Lilla, Mark (2007), The Stillborn God: religion, politics and the modern West, New York: Vintage Books.

Löwith, Karl (1949), Meaning in History, Chicago: University of Chicago Press. 
Louth, Andrew (1981), The Origins of the Christian Mystical Tradition: from Plato to Denys, Oxford: Clarendon Press.

McFarland, A Ian (2014), From Nothing: a theology of creation, Louisville, Kentucky: Westminster John Knox Press.

McFarland, A. Ian (2010), In Adam's Fall: a meditation of the Christian Doctrine of Original Sin, Chichester: Wiley-Blackwell.

McIntyre, Alasdair (1990), Three Rival Versions of Moral Inquiry, London: Duckworth.

Meier, Heinrich (1995), Carl Schmitt and Leo Strauss: the Hidden Dialogue, Chicago: University of Chicago Press.

Modelski, George, 'Globalisation as Evolutionary Process' in George Modelski et al eds., Globalisation as Evolutionary Process: modelling global change, 11-29, London and New York: Routledge.

Molloy, Sean (2013), 'An 'All-Unifying Church Triumphant' A Neglected Dimension of Kant's Theory of International Relations', International History Review 35(2): 317-36.

Mühlenberg, Ekkehard (1993), 'Synergism in Gregory of Nyssa' in Everett Ferguson ed., Studies in Early Christianity: a collection of scholarly essays, New York and London: Garland Publishing.

Mulhall, Stephen (2005), Philosophical Myths of the Fall, Princeton, N.J.: Princeton University Press.

Neumann, B. Iver (2014), 'International Relations as a Social Science', Millennium: Journal of International Studies 43(1): 330-350.

Nicholson, Michael (2002), International Relations: A Concise Introduction, $2^{\text {nd }}$ ed. Basingstoke: Palgrave Macmillan.

Niebuhr, Reinhold (1953), 'Augustine's Political Realism', in Niebuhr, Christian Realism and Political Problems, 119-46, New York: New York: Charles Scribner's Sons.

Niebuhr, Reinhold (1941), The Nature and Destiny of Man: a Christian interpretation, vol. I Human Nature, London: Nisbet \& Co.

Niebuhr, Reinhold (1935), An Interpretation of Christian Ethics, New York: Harper \& Row.

Nietzsche, Friedrich (1967), On the Genealogy of Morals, trans. W. Kaufmann and RJ Hollingdale, New York: Vintage Books.

Paipais, Vassilios (2015), 'Overcoming 'Gnosticism': Realism as Political Theology', Cambridge Review of International Affairs (online advance publication). 
Paipais, Vassilios (2013), 'Necessary Fiction: Realism's tragic theology', International Politics 50(6): 846-862.

Pinker, Steven (2002), Blank Slate: the modern denial of human nature, New York: Viking Penguin.

Rawls, John (2009), A Brief Inquiry into the Meaning of Sin and Faith, ed. Thomas Nagel, Cambridge Mass.: Harvard University Press.

Rengger, Nicholas (2013), 'On Theology and International Relations: world politics beyond the empty sky', International Relations 27(2): 141-157.

Ricoeur, Paul (2004), 'Original Sin: a study in meaning' in D. Ihde (ed.) The Conflict of Interpretations: essays in hermeneutics, 265-282, Evanston, Illinois: Northwestern University.

Rosen, Peter Stephen (2004), War and Human Nature, Princeton, NJ: Princeton University Press.

Schmitt, Carl (2008), Political Theology II: the myth of the closure of any political theology, Cambridge: Polity Press.

Sesboüe, SJ Bernard (2004), 'The Theological Rationalization of Original Sin' in Cristopher Boureux and Christoph Theobald eds., Original Sin: a code of fallibility, London: SCM Press.

Shaw, R. Paul and Wong, Yuwa (1987), 'Ethnic Mobilization and the Seeds of Warfare: An Evolutionary Perspective', International Studies Quarterly 31(1): 5-31.

Taylor, Charles (2007), A Secular Age, Cambridge, Mass.; London: Harvard University Press.

Taylor, Charles (1989), Sources of the Self: The Making of the Modern Identity, Cambridge, Mass.: Harvard University Press.

Thayer, Bradley (2004), Darwin and International Relations: on the evolutionary origins of war and ethnic conflict, Lexington: University Press of Kentucky.

Thayer, A. Bradley (2000), 'Bringing in Darwin: Evolutionary Theory, Realism, and International Politics', International Security 25(2): 124-51.

Theobald, Christoph (2004), “Original Sin': still disputed doctrine: reflections on a debate', in Cristopher Boureux and Christoph Theobald eds., Original Sin: a code of fallibility, London: SCM Press.

Waltz, Kenneth (1959), Man, State and War: a theoretical analysis, New York: Columbia University Press.

Wight, Martin (1948), 'The Church, Russia and the West', Ecumenical Review: A Quarterly 1(1): 25-45. 
Wiley, Tatha (2002), Original Sin: origins, developments, contemporary meanings, New York; Mahwah, N.J.: Paulist Press.

Wilson, O. Edward (1975), Sociobiology: the new synthesis, Cambridge, Mass.: Harvard University Press.

Wood, A. Allen (1999), Kant's Ethical Thought, Cambridge: Cambridge University Press.

Wood, W. Allen (1970), Kant's Moral Religion, Ithaca, NY: Cornell University Press. 